\title{
Aqueous extract of Psidium guajava leaves: phenolic compounds and inhibitory potential on digestive enzymes
}

\author{
ANDERSON A. SIMÃO, TAMARA R. MARQUES, SILVANA MARCUSSI and ANGELITA D. CORREA \\ Departamento de Química, Laboratório de Bioquímica, Universidade Federal de \\ Lavras/UFLA, Campus UFLA, 37200-000 Lavras, MG, Brazil
}

Manuscript received on March 7, 2016; accepted for publication on July 22, 2016.

\begin{abstract}
Leaves of Psidium guajava L. (guava) have been widely used in the popular way for prevention and treatment of various diseases. Thus, the objective of this study was to evaluate the inhibitory potential of leaves aqueous extract from three cultivars of P. guajava (Pedro Sato, Paluma and Século XXI) on $\alpha$-amylase, $\alpha$-glycosidase, lipase, and trypsin enzymes, in the presence or not of simulated gastric fluid and to determine the content of phenolic compounds by high performance liquid chromatography. All cultivars presented the same composition in phenolic compounds, but in different proportions. The compounds identified are gallic acid, epigallocatechin gallate, syringic acid, o-coumaric acid, resveratrol, quercetin, and catechin (which was the major compound in all the cultivars evaluated). In the absence of simulated gastric fluid, it was observed different inhibitions exercised by the leaves aqueous extracts from three cultivars of $P$. guajava on each enzyme. In presence of simulated gastric fluid, all cultivars showed increase in the inhibition of lipase and $\alpha$-glycosidase, and decrease in inhibition of $\alpha$-amylase and trypsin enzymes. These results indicate that $P$. guajava leaves aqueous extracts from all cultivars evaluated possess potential of use as an adjuvant in the treatment of obesity and other dyslipidemias.
\end{abstract}

Key words: medicinal plants, obesity, $\alpha$-amylase, $\alpha$-glycosidase, lipase, trypsin.

\section{INTRODUCTION}

Obesity is a disease resulting from the excessive accumulation of body fat, and due to the consequences caused by it and its rapid increase throughout the world, it has been considered a global epidemic, with over 1.9 billion overweight adults, from which 600 million are clinically obese. Between 1980 and 2014, the world's obesity

Correspondence to: Anderson Assaid Simão

E-mail: andersonbsbufla@yahoo.com.br prevalence doubled (World Health Organization - WHO 2015). Its incidence independent of socioeconomic factors and age, and its consequences range from the development of debilitating diseases (cardiovascular diseases, some types of cancer, muscle disturbs, hypertension, and type 2 diabetes mellitus) to death, directly affecting the quality of life of individuals (Wanderley and Ferreira 2010, WHO 2015).

Among the options available for the treatment of obesity, the most used ones are balanced diets, 
regular physical exercises, and drug treatments, ranging from lipase inhibitors to anorectics. However, due to side effects and the high cost of drugs traditionally used in the treatment of this disease, the potential of natural products for treatment of obesity have been widely explored, and they may be a viable alternative for future development of more effective and safe anti-obesity drugs (Park et al. 2005, Mayer et al. 2009). Mixtures of phytochemicals or isolated molecules identified from plants represent an excellent opportunity for the development of such therapeutics (Bhutani et al. 2007).

The phenolic compounds stands out among the bioactive substances in medicinal plants capable of generating new phytotherapic drugs, and that attends pharmaceutical industry interest. These compounds present several medicinal properties like antioxidants, anti-histamines, anti-inflammatory, antibacterial, anti-thrombotic (Balasundram et al. 2006), and can also be used as adjuvants in the treatment of obesity (Klaus et al. 2005, Hen et al. 2006, Alterio et al. 2007, SantiagoMora et al. 2011, Zhang et al. 2015, Vogel et al. 2015).

The action potential of phenolic compounds in the treatment and prevention of obesity is due to their thermogenic effects, which corresponds in ability to oxidize body fat, and decrease intestinal absorption of fats and carbohydrates. These effects are result of digestive enzymes inhibition, with consequent weight loss (Klaus et al. 2005, Alterio et al. 2007).

In this context, enzymes like $\alpha$-amylase and $\alpha$-glycosidase, responsible for processing dietary carbohydrates, acts on starch breakdown, resulting in monosaccharide absorption by enterocytes. Therefore, their inhibition offers a promising strategy for the prevention of obesity, as well as type 2 diabetes associated to hyperglycemia, by inhibiting starch breakdown and glucose absorption in the small intestine (Kwon et al. 2006, Balasubramanian et al. 2013).

Lipase, involved in fat metabolism, is also an important target for inhibitors, since its inhibition limits triacylglycerol absorption, leading to a decrease in caloric yield and weight loss. On the other hand, trypsin inhibition, involved in protein digestion, has a malefic effect, once it impairs the complete amino acid absorption in food, essential for the organism (Friedman and Brandon 2001).

Studies have shown the effectiveness and therapeutic potential of enzymes inhibitors in the treatment of obesity and associated comorbidities, reinforcing the need to search for new sources of natural inhibitors (Pereira et al. 2011a, Souza et al. 2011, Simão et al. 2012). Therefore, digestive inhibitors, which assist in reducing fat and carbohydrate absorption in the small intestine, may be useful helpers in the treatment of obesity.

Psidium guajava L., popularly known as guava, is an example of plant that stands out for its economic expression, taste, flavor, and diversity of possible uses. Gutiérrez et al. (2008) published a revision about guava highlighting pharmacological properties of bark, fruit, leaves, and roots, describing its antioxidant, hepatoprotective, anti-allergic, antimicrobial, anti-plasmodial, anti-diabetic, and antiinflammatory functions.

Although the fruit is the most significant part from $P$. guajava, teas, infusions, and decoctions prepared from its leaves have been used by people for medicinal purposes, in the treatment of gastroenteritis, fever, diarrhea, Chagas disease, ulcers, cholera, digestive problems, and others (Vendruscolo et al. 2005). However, many of these applications have no scientific evidence of a therapeutic effect, highlighting the importance of studies that bring information on the efficacy and safety of its use.

In the chemical composition of $P$. guajava leaves are found several bioactive compounds such as essential oils, saponins and phenolic 
compounds, highlighting thus, the pharmacological potential of these leaves and different perspectives to their therapeutic application (Haida et al. 2011). In addition, the leaves from $P$. guajava, shows rich composition in phenolic compounds, reinforcing the importance of investigations about their possible inhibitory effect on digestive enzymes.

Considering the increasing search for effective therapeutic alternatives, less expensive and of proven security, as well as the lack of scientific information for a wide use of the leaves of $P$. guajava, the objective of the present study was to evaluate the potential of leaves infusions from different cultivars of P. guajava (Paluma, Pedro Sato and Século XXI) as a source of $\alpha$-amylase, $\alpha$-glycosidase, lipase, and trypsin inhibitors, as well as determine the phenolic compounds by high performance liquid chromatography, contributing with information for its future use as an adjuvant in the treatment of obesity and associated diseases.

\section{MATERIALS AND METHODS}

\section{OBTENTION AND PREPARATION OF PLANT} SAMPLES

Fresh leaves, without lesions induced mechanically or by pathogens, of Psidium guajava L. (Paluma - PL, Pedro Sato - PS and Século XXI - SEC, cultivars) were collected in an orchard located in Lavras city, Minas Gerais, Brazil, $845 \mathrm{~m}$ altitude, latitude $21: 15^{\circ} \mathrm{S}$ and longitude $45.22^{\circ} \mathrm{W}$, in March 2015.

The leaves were identified by the College of Agriculture at Lavras Herbarium where a voucher specimen was deposited which received the voucher number: PL n ${ }^{\circ} 26276$, PS n ${ }^{\circ} 26277$ and SEC n ${ }^{\circ} 26278$.

The leaves were washed in running water, kept in a $0.1 \%$ sodium hypochlorite solution for 1 hour, washed in distilled water and dried in an oven for 48 hours, at a temperature of $35^{\circ} \mathrm{C}$. The dried leaves were ground in a Willey mill and the obtained powder was subjected to infusion in boiling water at a 1:25 $\left(\mathrm{w} \mathrm{v}^{-1}\right)$ ratio for 30 minutes. The extract was then centrifuged at $10,000 \mathrm{x} \mathrm{g}$ for 10 minutes (206 BL Fanem Baby ${ }^{\circledR I}$ ) and the supernatant was collected. The supernatants were then lyophilized (FreeZone LABCONCO 4.5 L benchtop lyophilizer) and weighed. Posteriorly, this lyophilized supernatant was dissolved in water, for use in the assays and named aqueous extract.

\section{IDENTIFICATION AND QUANTIFICATION OF PHENOLIC COMPOUNDS}

The high performance liquid chromatography (HPLC) was performed using a Shimadzu UHPLC chromatograph (Shimadzu Corporation, Kyoto, Japan) equipped with two LC-20AT high-pressure pumps, an SPD-M20A UV-Vis detector, a CTO20AC oven, a CBM-20A interface, and an automatic injector with an SIL-20A auto sampler. Separations were performed using a Shim-pack VP-ODS-C18 $(250 \mathrm{~mm} \times 4.6 \mathrm{~mm})$ column, connected to a Shimpack Column Holder $(10 \mathrm{~mm} \times 4.6 \mathrm{~mm})$ pre-column (Shimadzu, Japan).

The mobile phase consisted of the following solutions: $2 \%$ acetic acid in water (A) and methanol:water:acetic acid (70:28:2 v/v/v) (B). Analysis were performed for a total time of $65 \mathrm{~min}$ at $40{ }^{\circ} \mathrm{C}$, flux of $1 \mathrm{~mL} \mathrm{~min}{ }^{-1}$, wavelength of 280 $\mathrm{nm}$, and injection volume of $20 \mu \mathrm{L}$ in a gradienttype system (100\% solvent A from 0.01 to $5 \mathrm{~min}$; $70 \%$ solvent A from 5 to $25 \mathrm{~min} ; 60 \%$ solvent A from 25 to $43 \mathrm{~min}$; $55 \%$ solvent A from 43 to 50 min; and $0 \%$ solvent $A$ for $10 \mathrm{~min}$ ) until the end of the run. Solvent A was increased to $100 \%$, seeking to maintain a balanced column. Acetic acid and methanol (HPLC grade; Sigma-Aldrich, USA) were used in the preparation of the mobile phase.

The phenolic standards used as identification parameters were gallic acid, catechin, epigallocatechin gallate, epicatechin, syringic acid, $o$-coumaric acid, $p$-coumaric acid, ferulic acid, vanillin, salicylic acid, resveratrol, and quercetin, 
all obtained from Sigma-Aldrich (St. Louis, MO, USA). The stock standard solutions were prepared in methanol (HPLC grade; Sigma-Aldrich, USA).

The extracts and the standards were filtered through a $0.45-\mu \mathrm{m}$ nylon membrane (EMD Millipore, USA) and directly injected into the chromatographic system, in three replicates. The phenolic compounds in the extracts were identified by comparison with retention times of standards and by co-elution performing the elution of samples together with standards. Quantification was performed by the construction of analytical curves obtained by linear regression using Origin 6.1 computer software (OriginLab, Northampton, MA, USA) and considering the coefficient of determination $\left(\mathrm{R}^{2}\right)$ equal to 0.99 .

\section{ENZYME OBTENTION}

In these assays the following enzymes were used: porcine pancreatic lipase (EC 3.1.1.3) type II, Sigma; porcine pancreatic $\alpha$-amylase (EC 3.2.1.1) type VI B, Sigma and porcine pancreatic trypsin (EC 3.4.21.4), Merck. The $\alpha$-glycosidase (EC 3.2.1.20) was obtained from fresh porcine duodenum according to Simão et al. (2012).

\section{$\alpha$-AMYLASE ACTIVITY}

The $\alpha$-amylase activity was determined using the methodology proposed by Noelting and Bernfeld (1948). Thus, aqueous extracts and $\alpha$-amylase enzyme were pre-incubated for $20 \mathrm{~min}$, in a water bath at $37{ }^{\circ} \mathrm{C}$. The substrate was the $1 \%$ starch, prepared in Tris $0.05 \mathrm{~mol} \mathrm{~L}^{-1}, \mathrm{pH} 7.0$ buffer with $38 \mathrm{mmol} \mathrm{L}^{-1} \mathrm{NaCl}$ and $0.1 \mathrm{mmol} \mathrm{L}^{-1} \mathrm{CaCl}_{2}$. After that, $100 \mu \mathrm{l}$ of substrate were added and the mixture was incubated for four periods of time. The reaction was interrupted adding $200 \mu \mathrm{l}$ of 3.5 dinitrosalicylic acid and the product measured in spectrophotometer at $540 \mathrm{~nm}$.

\section{$\alpha$-GLYCOSIDASE ACTIVITY}

The $\alpha$-glycosidase activity was determined according to Kwon et al. (2006), using $5 \mathrm{mmol} \mathrm{L}^{-1}$ $p$-nitrophenyl- $\alpha$-D-glucopyranoside in a $0.1 \mathrm{~mol}$ $\mathrm{L}^{-1} \mathrm{pH} 7.0$ citrate-phosphate buffer as substrate. In the assay, aqueous extracts and $\alpha$-glycosidase enzyme were incubated in a water bath, at $37^{\circ} \mathrm{C}$, for four periods of time, and after that, the substrate was added. The reaction was interrupted adding $1.000 \mu \mathrm{l}$ of $0.05 \mathrm{~mol} \mathrm{~L}^{-1} \mathrm{NaOH}$ and the product was measured in a spectrophotometer at $410 \mathrm{~nm}$.

\section{LIPASE ACTIVITY}

The lipase activity was determined according to Simão et al. (2012), using $4 \mathrm{mmol} \mathrm{L}^{-1}$ $p$-nitrophenyllaurate in Tris- $\mathrm{HCl} 0.05 \mathrm{mmol} \mathrm{L}^{-1}$, pH 8.0 buffer containing $0.5 \%$ Triton-X100 as substrate. In this assay, aqueous extracts and lipase enzyme were incubated in a water bath, at $37^{\circ} \mathrm{C}$, for four periods of time, and after that, the substrate was added. The reaction was stopped, transferring the tubes to an ice bath and adding Tris- $\mathrm{HCl} 0.05$ mmol L ${ }^{-1}$ pH 8.0 buffer. The $p$-nitrophenol, of yellow coloration, a product of the lipase action on $p$-nitrophenyllaurate, was measured in a spectrophotometer at $410 \mathrm{~nm}$.

\section{TRYPSIN ACTIVITY}

The trypsin activity was determined according to the methodology proposed by Erlanger et al. (1961). Thus, aqueous extracts and trypsin were incubated in a water bath, at $37^{\circ} \mathrm{C}$, for four periods of time, and after that the $p$-benzoyl-DL-argininep-nitroanilide substrate (BAPNA), prepared in Tris $0.05 \mathrm{~mol} \mathrm{~L}^{-1}, \mathrm{pH} 8.2$, was added. The reaction was interrupted adding $200 \mu \mathrm{l}$ of $30 \%$ acetic acid and the product measured in a spectrophotometer at $410 \mathrm{~nm}$. 


\section{DETERMINATION OF INHIBITION}

For each assay of enzymatic activity, the concentrations of aqueous extract were different and its dilution ranged so that the enzyme inhibition ranged from $40 \%$ to $80 \%$, according to the methodology.

The inhibition of the enzymes were obtained from the determination of the slopes of the straight lines (absorbance $\mathrm{x}$ time) corresponding to values obtained for the control enzyme (without aqueous extract) and enzymes + inhibitor (with aqueous extract) in the activity assays. The slope of the straight line correspond to the speed of product formation per minute of reaction and the presence of the inhibitor causes a decrease of this inclination. The absorbance values were converted into micromoles of product based on data obtained from a standard curve elaborated with glucose for the amylase and with $p$-nitrophenol for glycosidase and lipase, while, for the trypsin, the molar extinction coefficient of BAPNA was determined by Erlanger et al. (1961).

\section{PREPARATION OF SIMULATED GASTRIC FLUID}

With the objective of simulating the digestion process in the stomach in vitro, enzymatic activity assays in the presence of a simulated gastric fluid were also carried out. For such, the aqueous extract was incubated with the simulated gastric fluid prepared according to The United States Pharmacopeia - USP (2005), for $1 \mathrm{~h}$ in a water bath at $37^{\circ} \mathrm{C}$. Subsequently, it was neutralized with sodium bicarbonate salt to $\mathrm{pH} 7.0$ and, only then, the activity assays were realized.

\section{STATISTICAL ANALYSIS}

All data were collected in three repetitions and presented as the mean \pm standard deviation. The data were statistically evaluated by analysis of variance, and the means were compared using the
Scott Knott test $(\mathrm{P}<0.05)$ with the aid of the $\mathrm{R}$ software (R Development Core Team 2012).

\section{RESULTS AND DISCUSSION}

Mass yield percentages obtained for the Paluma (PL), Pedro Sato (PS) and Século XXI (SEC) cultivars were $3.88 \pm 0.05 \%, 4.45 \pm 0.02 \%$ and $3.52 \pm 0.23 \%$, respectively.

In the figure 1 are demonstrated the chromatograms obtained to phenolic compounds presents in the leaves aqueous extracts from $P$. guajava cultivars and the phenolic compounds used as standards. The results of chromatographic analysis to the phenolic compounds quantification in the leaves aqueous extracts from P. guajava cultivars are presented in Table I. All cultivars showed the same phenolic composition but with different levels of gallic acid, catechin, epigallocatechin gallate, syringic acid, $o$-coumaric acid, resveratrol, and quercetin.

The catechin was the major compound between phenolic compounds identified in the cultivars, followed by gallic acid and resveratrol, however the levels vary in the different cultivars, except for gallic acid. The cultivar PL presented the highest level of catechin; PS of epigallocatechin gallate and resveratrol; and the SEC of syringic acid, o-coumaric acid and quercetin. The PL cultivar presented the highest content of total phenolic compounds.

The compounds epicatechin, $p$-coumaric acid, ferulic acid, vanillin, and salicylic acid were not identified in the aqueous extract of the leaves of three cultivars of $P$. guajava.

Phenolic compounds, such as caffeic and chlorogenic acid, catechin, epigallocatechin gallate and quercetin have thermogenic effect, ability to oxidize fats, control appetite, regulate levels of hormones related to obesity and inhibit digestive enzymes involved in the absorption of carbohydrates and lipids (Lin and Lin-Shiau 2006, Alterio et al. 

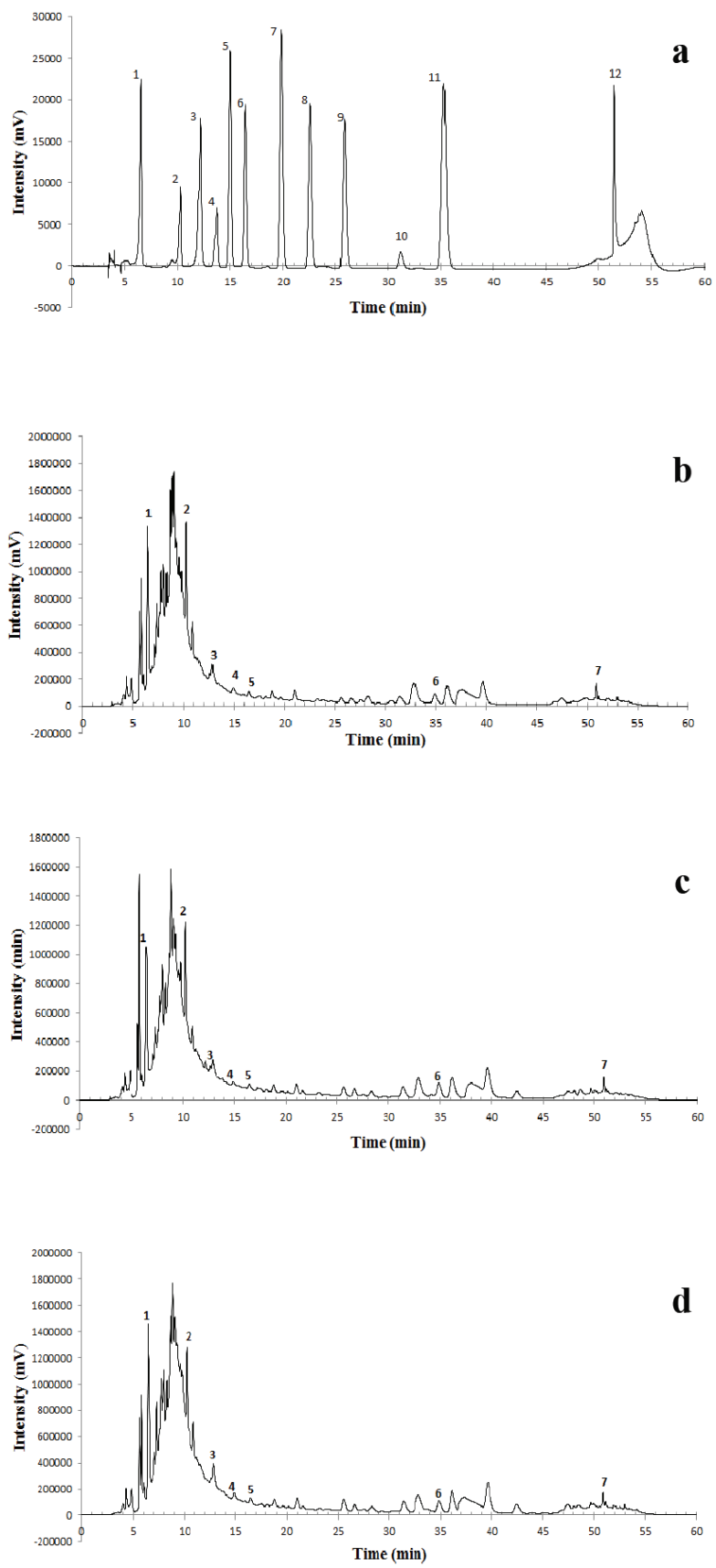

Figure 1 - Chromatogram of phenolic compounds in the aqueous extract of the leaves from three cultivars of Psidium guajava. (a) Identification standards: $1=$ Gallic acid; $2=$ Catechin; 3 = Epigallocatechin gallate; $4=$ Epicatechin; $5=$ Syringic acid; $6=o$-coumaric acid; $7=p$-coumaric acid; $8=$ Ferulic acid; 9 = Vanillin; $10=$ Salicylic acid; $11=$ Resveratrol; 12 = Quercetin. (b) Paluma. (c) Pedro Sato. (d) Século XXI.
TABLE I

Phenolic compounds, in $\mathrm{mg}^{100 \mathrm{~g}^{-1}}$, present in the aqueous extract of the leaves from three cultivars of Psidium guajava.

\begin{tabular}{lccc}
\hline $\begin{array}{l}\text { Phenolic } \\
\text { compound }\end{array}$ & Paluma & $\begin{array}{c}\text { Pedro } \\
\text { Sato }\end{array}$ & $\begin{array}{c}\text { Século } \\
\text { XXI }\end{array}$ \\
\hline Gallic acid & $681.12 \pm$ & $650.08 \pm$ & $630.38 \pm$ \\
& $35.76^{\mathrm{Ba}}$ & $3.25^{\mathrm{Ba}}$ & $21.95^{\mathrm{Ba}}$ \\
Catechin & $846.19 \pm$ & $756.31 \pm$ & $771.97 \pm$ \\
& $9.84^{\mathrm{Aa}}$ & $30.73^{\mathrm{Ab}}$ & $16.64^{\mathrm{Ab}}$ \\
Epigallocatechin & $10.30 \pm$ & $61.04 \pm$ & $6.29 \pm$ \\
gallate & $0.15^{\mathrm{Fb}}$ & $6.40^{\mathrm{Da}}$ & $0.25^{\mathrm{Fc}}$ \\
Syringic acid & $22.70 \pm$ & $14.17 \pm$ & $27.91 \pm$ \\
& $1.52^{\mathrm{Db}}$ & $0.46^{\mathrm{Ec}}$ & $0.34^{\mathrm{Ea}}$ \\
o-Coumaric acid & $11.17 \pm$ & $11.86 \pm$ & $36.66 \pm$ \\
& $0.09^{\mathrm{Eb}}$ & $1.02^{\mathrm{Fb}}$ & $2.04^{\mathrm{Da}}$ \\
Resveratrol & $71.03 \pm$ & $93.77 \pm$ & $61.74 \pm$ \\
& $5.78^{\mathrm{Cb}}$ & $4.78^{\mathrm{Ca}}$ & $0.81^{\mathrm{Cc}}$ \\
Quercetin & $0.03 \pm$ & $0.03 \pm$ & $0.07 \pm$ \\
& $0.00^{\mathrm{Gb}}$ & $0.00^{\mathrm{Gb}}$ & $0.01^{\mathrm{Ga}}$ \\
E Phenolic & $1,642.54$ & $1,587.26$ & $1,535.02$ \\
compounds & & & \\
\hline
\end{tabular}

Data from three repetitions, with mean \pm standard deviation. Uppercase letters in columns compare among phenolic compounds and lowercase on the lines compare among cultivars. Same letters do not differ among themselves by the Scott-Knott test at 5\% probability.

2007, Cho et al. 2010, Rains et al. 2011). Thus, this study shows that the aqueous extract of the leaves from $P$. guajava presents potential to be explored by the pharmaceutical industry in search of drugs to control obesity and related diseases.

The results for enzymatic inhibition of aqueous extract of the leaves of three cultivars of P. guajava are shown in Table II. All enzymes studied were inhibited by $P$. guajava (PS, P and SEC) leaves extracts, before and after exposure to simulated gastric fluid.

For $\alpha$-amylase enzyme, SEC cultivar induced an inhibition significantly greater than the other cultivars, before the exposure to gastric fluid (Table II), but, after exposure to gastric fluid, there was no significant difference among the three cultivars. 
However, a decrease in enzyme inhibition of $19.20 \%$ (PS) to $25.42 \%$ (SEC), was observed.

The inhibitory potential presented by the $P$. guajava aqueous extract, from different cultivars, exceeds the one found by Pereira et al. (2011b), who analyzed the white bean crude extract and detected

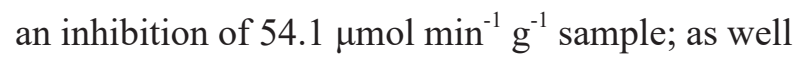
as those from Simão et al. (2012), that studying aqueous extracts of medicinal plants, observed an

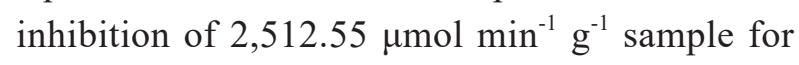
Tournefortia paniculata Cham (marmelinho).

Infusions, decoctions, and teas rich in $\alpha$-amylase inhibitors appears to be an interesting strategy in the prevention and treatment of hyperglycemia, by slowing postprandial glucose levels in blood after the ingestion of carbohydrates (Vadivel et al. 2011).

The PL cultivar induced the greatest inhibitory activity of $\alpha$-glycosidase, before and after exposure to gastric fluid (Table II). The inhibition of $\alpha$-glycosidase by the aqueous extract of the leaves from three cultivars found in this paper surpasses the ones verified by Simão et al. (2012), who, studying the aqueous extracts of medicinal plants, found inhibitions of $1.23 \mu \mathrm{mol} \mathrm{min} \mathrm{mg}^{-1} \mathrm{~g}^{-1}$ dry matter for Aloe vera (L.) Burm., and 0.58 umol $\mathrm{min}^{-1}$ $\mathrm{g}^{-1}$ dry matter for Baccharis trimera (Less.) DC, which are lower than values found for Tournefortia paniculata Cham. (5.46 $\mu \mathrm{mol} \mathrm{min}^{-1} \mathrm{~g}^{-1}$ dry matter), as well as those described by Pereira et al. (2011a), who analyzed commercial samples of Hoodia gordonni, used as an auxiliary in the treatment of obesity and found inhibitions of 10.40 e 16.70 $\mu \mathrm{mol} \min ^{-1} \mathrm{~g}^{-1}$ dry matter.

The inhibition of $\alpha$-glycosidase extends gastric emptying, leading to satiety and weight loss, effects that can be useful in the treatment of obesity (Chen et al. 2008). Therefore, the inhibition of $\alpha$-amylase and $\alpha$-glycosidase by natural products can provide an alternative for the treatment of obesity in substitution to synthetic drugs, besides controlling
TABLE II

Inhibition of digestive enzymes by aqueous extract of the leaves from three cultivars of Psidium guajava, before and after exposure to simulated gastric fluid.

\begin{tabular}{|c|c|c|c|}
\hline \multirow[b]{2}{*}{ Enzyme } & \multirow[b]{2}{*}{ Cultivar } & \multicolumn{2}{|c|}{ Inhibition (IEU $\left.{ }^{1}\right)^{*}$} \\
\hline & & $\begin{array}{c}\text { Before } \\
\text { exposure }\end{array}$ & $\begin{array}{c}\text { After } \\
\text { exposure }\end{array}$ \\
\hline \multirow{3}{*}{$\alpha$-amylase } & Paluma & $\begin{array}{c}13,776.93 \pm \\
79.18^{\mathrm{Ba}}\end{array}$ & $\begin{array}{l}10,633.73 \\
\pm 58.05^{\mathrm{Ab}}\end{array}$ \\
\hline & Pedro Sato & $\begin{array}{c}13,130.47 \pm \\
21.94^{\mathrm{Ca}}\end{array}$ & $\begin{array}{r}10,608.40 \\
\pm 100.54^{\mathrm{Ab}}\end{array}$ \\
\hline & $\begin{array}{l}\text { Século } \\
\text { XXI }\end{array}$ & $\begin{array}{c}14,410.60 \pm \\
38.00^{\mathrm{Aa}}\end{array}$ & $\begin{array}{l}10,747.73 \\
\pm 58.05^{\mathrm{Ab}}\end{array}$ \\
\hline \multirow{3}{*}{$\alpha$-glycosidase } & Paluma & $2.28 \pm 0.02^{\mathrm{Ab}}$ & $\begin{array}{l}2.59 \pm \\
0.06^{\text {Aa }}\end{array}$ \\
\hline & Pedro Sato & $2.20 \pm 0.02^{\mathrm{Bb}}$ & $\begin{array}{l}2.33 \pm \\
0.04^{\mathrm{Ba}}\end{array}$ \\
\hline & $\begin{array}{l}\text { Século } \\
\text { XXI }\end{array}$ & $1.99 \pm 0.04^{\mathrm{Cb}}$ & $\begin{array}{l}2.38 \pm \\
0.04^{\mathrm{Ba}}\end{array}$ \\
\hline \multirow{3}{*}{ Lipase } & Paluma & $\begin{array}{c}28.82 \pm \\
0.79^{\mathrm{Cb}}\end{array}$ & $\begin{array}{c}33.15 \pm \\
1.64^{\mathrm{Ca}}\end{array}$ \\
\hline & Pedro Sato & $\begin{array}{c}36.45 \pm \\
0.68^{\mathrm{Ab}}\end{array}$ & $\begin{array}{c}43.33 \pm \\
1.80^{\mathrm{Aa}}\end{array}$ \\
\hline & $\begin{array}{l}\text { Século } \\
\text { XXI }\end{array}$ & $\begin{array}{c}31.89 \pm \\
0.45^{\mathrm{Bb}}\end{array}$ & $\begin{array}{c}38.20 \pm \\
1.17^{\mathrm{Ba}}\end{array}$ \\
\hline \multirow{4}{*}{ Trypsin } & Paluma & $\begin{array}{l}142,075.70 \\
\pm 918.22^{\mathrm{Ba}}\end{array}$ & $\begin{array}{l}21,470.40 \\
\pm 795.20^{\mathrm{Ab}}\end{array}$ \\
\hline & Pedro Sato & $\begin{array}{c}124,051.20 \\
\pm 4,207.80^{\mathrm{Ca}}\end{array}$ & $\begin{array}{c}11,132.8 \pm \\
791.31^{\mathrm{Cb}}\end{array}$ \\
\hline & Século & $147,377.10$ & $15,108.8 \pm$ \\
\hline & XXI & $\pm 918.21^{\mathrm{Aa}}$ & $1,590.40^{\mathrm{Bb}}$ \\
\hline
\end{tabular}

Data from three repetitions, with mean \pm standard deviation. ${ }^{1}$ IEU $=$ Inhibited Enzyme Unit in $\mu \mathrm{mol} \mathrm{min}^{-1} \mathrm{~g}^{-1}$ sample. *The aqueous extract of the leaves from three cultivars of the Psidium guajava measured for each of the enzymes was diluted to provide an inhibition between $40 \%$ and $80 \%$, in order to ensure result reliability. Uppercase letters in columns compare among cultivars and lowercase on the lines compare before and after the exposure to simulated gastric fluid. Same letters do not differ among themselves by the Scott-Knott test at $5 \%$ probability.

glucose levels in blood in type 2 diabetes patients (McDougall et al. 2005a).

A greater lipase inhibition was observed to PS cultivar and the lower inhibition to PL, before and after exposure to gastric fluid (Table II).

Studies show the presence of lipase inhibitors in alcoholic vegetal extracts mainly methanolic 
extracts (Sharma et al. 2005, Sugimoto et al. 2009, Souza et al. 2011). These studies suggest that organic compounds soluble in methanol, exhibit some structural feature that results in binding and inhibition of pancreatic lipase. The three aqueous extracts from $P$. guajava varieties, analyzed in this study, demonstrated an inhibitory potential of pancreatic lipase, and the phenolic compounds may be responsible for this inhibition, since these compounds are also present in medicinal plant alcoholic extracts.

The three varieties of $P$. guajava induced high percentages of inhibition of the trypsin activity before exposure to gastric fluid, having a significant reduction in inhibitory activity after exposure to gastric fluid, ranging from $84.88 \%$ (PL) at $91.02 \%$ (PS).

When trypsin inhibitors are present in the diet, these may lead to a reduction in growth rate in animals, followed by a decrease in protein digestibility, leading to weight loss and endogenous protein catabolism (McDougall et al. 2005a). Therefore, the trypsin inhibitors are considered as anti-nutritional factors. Thus, this reduction in trypsin inhibition, after exposure to gastric fluid, is considered positive, since protein digestibility is little affected.

In this study, the inhibition of digestive enzymes can probably be explained by the presence of phenolic compounds in the aqueous extract of the leaves from three P. guajava cultivars, whose levels were different for each cultivar assessed (Table I). PL cultivar, that showed the highest content of catechin, exerted greater inhibition on $\alpha$-glycosidase enzyme, the PS, with the major content of epigallocatechin gallate and resveratrol, showed the greatest inhibition on lipase, while SEC cultivar, rich in syringic acid, o-coumaric acid and quercetin, showed greater potential inhibition on the $\alpha$-amylase and trypsin enzymes. The synergy between the phenolic compounds must be taken in account for a better understanding of the inhibitory action of the extracts on digestive enzymes.

In the present study, among the phenolic compounds identified in the leaves from P. guajava, gallic acid is considered a hydrolysable tannin, when found in the form of gallic acid esters, while catechin and epicatechin gallate, when found in the form of flavonoids, are considered condensed tannins. These compounds have strong interactions with metal ions and macromolecules such as polysaccharides, besides the ability to form soluble complexes with several proteins, as digestives enzymes (Won et al. 2007, Gholamhoseinian et al. 2010).

Several studies have shown that phenolic compounds present in medicinal plants and fruits have anti-obesity properties by exerting different mechanisms of action, especially by inhibition of digestive enzymes.

McDougall et al. (2005b) reported that red fruit extracts rich in phenolic compounds inhibit $\alpha$-amylase and $\alpha$-glycosidase, in vitro. In a similar way, recent studies with red fruits reported inhibition of $\alpha$-amylase and $\alpha$-glycosidase, and mentioned that tannins were the most effective compounds in inhibiting these enzymes (Boath et al. 2012). Kam et al. (2013) described that the methanol extract from the pomegranate flower, where the phenolic compounds gallic acid and ellagic acid are found, exhibits a potent inhibitory effect on $\alpha$-amylase and $\alpha$-glycosidase enzymes.

Studies conducted in vivo by Klaus et al. (2005) demonstrated that rats fed with diet supplemented by epigallocatechin gallate, purified from green tea, had an obesity decrease, due to a reduction in energy absorption and an increase in lipid oxidation. In other study, Bryans et al. (2007) reported that black tea is efficient in reducing postprandial blood glucose levels and related this fact to the presence of phenolic compounds such as epigallocatechin, epigallocatechin gallate, epicatechin, and epicatechin gallate. 
Wenzel (2013) reported that quercetin limits carbohydrate digestion and controls postprandial glucose levels in blood, thus confirming the result obtained by Tadera et al. (2006), who reported the inhibitory activity of quercetin on $\alpha$-amylase.

Other anti-obesity action mechanism attributed to flavonoids is by their ability to affect the sympathetic nervous system through the modulation of noradrenaline, thus increasing thermogenesis and fat oxidation. It also prevents the increase in the size and number of adipocytes, therefore preventing the deposition of fat in the body and regulating body weight (Lin and LinShiau 2006).

Phenolics, like $p$-hydroxybenzoic acid, syringic acid, trans- $p$-coumaric acid, epicatechin gallate, quercetin and kaempferol presents in lentil extracts, showed to be effective inhibitors of lipase and $\alpha$-glycosidase, contributing to control glucose levels in blood, as well as obesity (Zhang et al. 2015).

In addition, the aqueous extract of leaves from Tournefortia paniculata Cham., rich in phenolic compounds (Simão et al. 2014) presented in vitro inhibition of the $\alpha$-amylase and $\alpha$-glycosidase enzymes before and after exposure to gastric fluid simulation (Simão et al. 2012), and later, when administered to Wistar rats submitted to high calorie diet resulted in weight, food intake, liver fat, glucose and serum triglycerides reduction (Simão et al. 2015). The results described by these authors highlights the resistance of inhibitors present in $P$. guajava leaves to go through simulated gastric fluid, there is maintenance of inhibitory action in vivo.

Most phenols previously mentioned were found in the aqueous extract of the leaves from three cultivars of $P$. guajava, which could have led to a complexation with digestive enzymes, contributing to its inhibition. The inhibition of digestive enzymes by these compounds is a promising alternative for the treatment of obesity and type 2 diabetes, especially because they act in the small intestine, without acting in the central nervous system, where anorexigenic drugs usually act.

\section{CONCLUSIONS}

The aqueous extracts of leaves from Psidium guajava (Paluma, Pedro Sato and Século XXI) that contains the phenolic compounds gallic acid, catechin, epicatechin gallate, syringic acid, $o$-cumaric acid, resveratrol, and quercetin, were able to inhibit in vitro the digestive enzymes $\alpha$-amylase, $\alpha$-glycosidase, and lipase, with less inhibitory effect on trypsin, after exposure to simulated gastric fluid. The data shows that the aqueous extract of the leaves from Psidium guajava cultivars may represent a good source of inhibitors and can be used as an auxiliary in the treatment of obesity, associated comorbidities and in the control of type 2 diabetes.

\section{ACKNOWLEDGMENTS}

The authors would like to thank Fundação de Amparo à Pesquisa do Estado de Minas Gerais (FAPEMIG), Coordenação de Aperfeiçoamento de Pessoal de Nível Superior (CAPES) and Conselho Nacional de Desenvolvimento Científico e Tecnológico (CNPq) for the grants provided.

\section{REFERENCES}

ALTERIO AA, FAVA DAF AND NAVARRO F. 2007. Interaction of the daily ingestion of Green tea (Camellia sinensis) in the cellular metabolism and the adipose cell promoting emagrecimento. Rev Bras Obes Nut Emag 1: 27-37.

BALASUBRAMANIAN V, MUSTAR S, KHALID NM, RASHED AA, NOH MFM, WILCOX MD, PETER IC, BROWNLEE IA AND PEARSON JP. 2013. Inhibitory activities of three Malaysian edible seaweeds on lipase and a-amylase. J Appl Phycol 25: 1405-1412.

BALASUNDRAM N, SUNDRAM K AND SAMMAR S. 2006. Phenolic compounds in plants and agri-industrial byproducts: Antioxidant activity, occurrence, and potential uses. Food Chem 99: 191-203. 
BHUTANI KK, BIRARI R AND KAPAT K. 2007. Potential anti-obesity and lipid lowering natural products: a review. Nat Prod Commun 2: 331-348.

BOATH AS, GRUSSU D, STEWANT D AND MCDOUGALL G. 2012. Berry polyphenols inhibit digestive enzymes: a source of potential helth benefits? Food Dig 3: 1-7.

BRYANS JA, JUDD PA AND ELLIS PR. 2007. The effect of consuming instant black tea on postprandial plasma glucose and insulin concentrations in healthy humans. $\mathrm{J}$ Am Coll Nutr 26: 471-477.

CHEN X, XU G, LI X, LI Z AND YING H. 2008. Purification of an $\alpha$-amylase inhibitor in a polyethylene glycol/ fructose-1,6-bisphosphate trisodium salt aqueous twophase system. Process Biochem 43: 765-768.

CHO AS, JEON SM, KIM MJ, YEO J, SEO KL, CHOI MS AND LEE MK. 2010. Chlorogenic acid exhibits antiobesity property and improves lipid metabolism in high-fat diet-induced-obese mice. Food Chem Toxicol 48: 937-943.

ERLANGER BF, KUKOWSKY N AND COHEN W. 1961. The preparation and properties of two new chromogenic substrates of trypsin. Arch Biochem Biophys 95: 271-278.

FRIEDMAN M AND BRANDON DL. 2001. Nutritional and health benefits of soy proteins. J Agric Food Chem 49: 1069-1086.

GHOLAMHOSEINIAN A, SHAHOUZEHI B AND SHARIFI-FAR F. 2010. Inhibitory effect of some plant extracts on pancreatic lipase. Int J Pharm 6: 18-24.

GUTIÉRREZ RM, MITCHELL S AND SOLIS RV. 2008. Psidium guajava: a review of its traditional uses, phytochemistry and pharmacology. J Ethnopharmacol 117: 1-27.

HAIDA KS, BARON A, HAIDA KS, FACI D, HAAS J AND SILVA FJ. 2011. Compostos fenólicos totais e atividade antioxidante de duas variedades de goiaba e arruda. Rev Bras Cienc Saude 9.

HEN Q, LV Y AND YAO K. 2006. Effects of tea polyphenols on the activities of $\alpha$ - amylase, pepsin, trypsin and lipase. Food Chem 101: 1178-1182.

KAM A, LI KM, RAZMOVSHI-NAUMOVSHI V, NAMMI S, SHI J, CHAN K AND LI GQ. 2013. A comparative study on the inhibitory effects of different parts and chemical constituents of pomegranate on $\alpha$-amylase and $\alpha$-glucosidase. Phytother Res 27: 1614-1620.

KLAUS S, PULTZ S, THONE-REINEKE C AND WOLFRAM S. 2005. Epigallocatechin gallate attenuates diet-induced obesity in mice by decreasing energy absorption and increasing fat oxidation. Int J Obesi 29: 615-623.

KWON YI, APOSTOLIDIS E AND SHETTY K. 2006. Inhibitory potential of wine and tea against $\alpha$-amylase and $\alpha$-glucosidase for management of hyperglycemia linked to type 2 diabetes. J Food Biochem 32: 15-31.
LIN JK AND LIN-SHIAU SY. 2006. Mechanisms of hypolipidemic and anti-obesity effects of tea polyphenols. Mol Nutr Food Res 50: 211-217.

MAYER MA, HOCHT C, PUYO A AND TAIARA CA. 2009. Recent advances in obesity pharmacotherapy. Curr Clin Pharmacol 4: 53-61.

MCDOUGALL GJ, FIFFE S, DOBSON P AND STEWART D. 2005b. Anthocyanins from red wine - Their stability under simulated gastrointestinal digestion. Phytochem 66: 2540-2548.

MCDOUGALL GJ, SHPIRO F, DOBSON P, SMITH P, BLAKE A AND STEWART D. 2005a. Different polyphenolic components of soft fruits inhibit $\alpha$-amylase and $\alpha$-glucosidase. J Agric Food Chem 53: 2760-2766.

NOELTING G AND BERNFELD P. 1948. Sur les enzymes amylolytiques - III. La $\beta$-amylase: dosage d'activité et contrôle de l'absence d' $\alpha$-amylase. Helv Chim Acta 31: 286-290.

PARK MY, LEE KS AND SUNG MK. 2005. Effects of dietary mulberry, Korean red ginseng, and banaba on glucose homeostasis in relation to PPAR- $\alpha$, PPAR- $\gamma$, and LPL mRNA expressions. Life Sci 77: 3344-3354.

PEREIRA CA, PEREIRA LLS, CORRÊA AD, CHAGAS PMB, SOUZA SP AND SANTOS CD. 2011a. Inhibition of digestive enzymes by commercial powder extracts of Hoodia gordonii. Rev Bras Biociên 9: 265-269.

PEREIRA LLS, SANTOS CD, SÁTIRO LC, MARCUSSI S, PEREIRA CA AND SOUZA SP. 2011b. Inhibitory activity and stability of the white bean flour extract on digestive enzymes in the presence of simulated gastric fluid. Rev Bras Farm 92: 367-372.

RAINS TM, AGARWAL S AND MAKI KC. 2011. Antiobesity effects of green tea catechins: a mechanistic review. J Nutr Biochem 22: 1-7.

R CORE TEAM. 2012. R: A language and environment for statistical computing. Viena: R Foundation for Statistical Computing; 2012. ISBN 3-900051-07-0. Available: http:// www.R-project.org/.

SANTIAGO-MORA R, CASADO-DÍAZ A, CASTRO MD AND QUESADA-GÓMEZ JM. 2011. Oleuropein enhances osteoblastogenesis and inhibits adipogenesis: the effect on differentiation in stem cells derived from bone marrow. Osteoporos Int 22: 675-684.

SHARMA N, SHARMA VK AND SEO SY. 2005. Screening of some medicinal plants for anti-lipase activity. J Ethnopharmacol 97: 453-456.

SIMÃO AA, CORRÊA AD AND CHAGAS PMB. 2012. Inhibition of digestive enzymes by medicinal plant aqueous extracts used to aid the treatment of obesity. J Med Plants Res 6: 5826-5830.

SIMÃO AA, CORRÊA AD, LAGE FF, FREIRE JM, SILVA JS, FRAGUAS RM, BRAGA MA, QUEIROZ ER AND OLIVEIRA FA. 2014. Chemical composition of medicinal 
plants used as auxiliary treatments for obesity. Afr J Biotechnol 13: 3840-3846.

SIMÃO AA, RAMOS VO, CORRÊA AD, SOUSA RV AND MARCUSSI S. 2015. Anti-obesity Effects of the Administration of Tournefortia paniculata Cham Extract on Wistar Rats Subjected to a Hypercaloric Diet. Braz Arch Biol Technol 58: 494-503

SOUZA SP, PEREIRA LLS, SOUZA AA AND SANTOS CD. 2011. Inhibition of pancreatic lipase by extracts of Baccharis trimera (Less.) DC. Asteraceae: evaluation of antinutrients and effect on glycosidases. Rev Bras Farmacogn 21: 450-455.

SUGIMOTO S, NAKAMURA S, YAMAMOTO S, YAMASHITA C, ODA Y, MATSUDA H AND YOSHIKAWA M. 2009. Brazilian natural medicines. III. Structures of triterpene oligoglycosides and lipase inhibitors from Mate, leaves of Ilex paraguarienses. Biol Pharm Bull 57: 257-261.

TADERA K, MINAMI Y, TAKAMATSU K AND MATSUOKA T. 2006. Inhibition of $\alpha$-glucosidase and $\alpha$-amylase by flavonoids. J Nutr Sci Vitaminol 52: 149153.

THE UNITED STATES PHARMACOPEIA. 2005. The national formulary NF 18 (Pharmacopeial Convention Ing). Rockvile.

VADIVEL V, NANDETY A AND BIESALSKI HK. 2011. Antioxidant, free radical scavenging and type II diabetes- related enzyme inhibition properties of traditionally processed Jequirity bean (Abrus pecatorius L.). Int J Food Sci Technol 46: 2505-2512.

VENDRUSCOLO GS, RATES SMK AND MENTZ LA. 2005. Dados químicos e farmacológicos sobre as plantas utilizadas como medicinais pela comunidade do bairro Ponta Grossa, Porto Alegre, Rio Grande do Sul. Rev Bras Farmacogn 15: 361-372.

VOGEL P, MACHADO IK, GARAVAGLIA J, ZANI VT, SOUZA D AND DAL BOSCO SM. 2015. Polyphenols benefits of olive leaf (Olea europaea L.) to human health. Nutr Hosp 31: 1427-1433.

WANDERLEY EM AND FERREIRA VA. 2010. Obesity: a plural perspective. Cienc Saúde Coletiva 15: 185-194.

WENZEL U. 2013. Flavonoids as drugs at the small intestinal level. Curr Opin Pharmacol 13: 864-868.

WHO - WORLD HEALTH ORGANIZATION. 2015. Obesity and overweight. http://www.who.int/mediacentre/ factsheets/fs311/en/, access in March 2015.

WON S, KIM S AND KIM Y. 2007. Licochalcone A: A lipase inhibitor from the roots of Glycyrrhiza uralensis. Food Res Int 40: 1046-1050.

ZHANG B, DENG Z, RAMDATH DD, TANG, Y, CHEN PX, LIU R, LIU Q AND TSAO R. 2015. Phenolic profiles of 20 canadian lentil cultivars and their contribution to antioxidant activity and inhibitory effects on $\alpha$-glucosidase and pancreatic lipase. Food Chem 172: 675-684. 